\title{
Marine Fish Primary Hepatocyte Isolation and Culture: New Insights to Enzymatic Dissociation Pancreatin Digestion
}

\author{
Neusa Figueiredo ${ }^{1}$, Beatriz Matos ${ }^{1}$, Mário Diniz ${ }^{2} \mathbb{D}$, Vasco Branco ${ }^{3} \mathbb{D}$ and Marta Martins ${ }^{1,2, *}$ \\ 1 MARE-Marine and Environmental Sciences Centre, Departamento de Ciências e Engenharia do Ambiente, \\ NOVA School of Science and Technology (FCT NOVA), 2829-516 Almada, Portugal; \\ nl.figueiredo@campus.fct.unl.pt (N.F.); bi.matos@campus.fct.unl.pt (B.M.) \\ 2 UCIBIO-Applied Molecular Biosciences Unit, NOVA School of Science and Technology (FCT NOVA), \\ 2829-516 Almada, Portugal; mesd@fct.unl.pt \\ 3 Research Institute for Medicines (iMed.ULisboa), Faculty of Pharmacy, Universidade de Lisboa, \\ 1649-003 Lisboa, Portugal; vasco.branco@ff.ulisboa.pt \\ * Correspondence: marta.martins@fct.unl.pt; Tel.: +351-212-948-300
}

Citation: Figueiredo, N.; Matos, B.; Diniz, M.; Branco, V.; Martins, M. Marine Fish Primary Hepatocyte Isolation and Culture: New Insights to Enzymatic Dissociation Pancreatin Digestion. Int. J. Environ. Res. Public Health 2021, 18, 1380. https:// doi.org/10.3390/ijerph18041380

Academic Editor: Paul B. Tchounwou Received: 31 December 2020

Accepted: 31 January 2021

Published: 3 February 2021

Publisher's Note: MDPI stays neutral with regard to jurisdictional claims in published maps and institutional affiliations.

Copyright: (C) 2021 by the authors Licensee MDPI, Basel, Switzerland. This article is an open access article distributed under the terms and conditions of the Creative Commons Attribution (CC BY) license (https:// creativecommons.org/licenses/by/ $4.0 /)$

\begin{abstract}
Primary cell cultures from wild organisms have been gaining relevance in ecotoxicology as they are considered more sensitive than immortalized cell lines and retain the biochemical pathways found in vivo. In this study, the efficacy of two methods for primary hepatocyte cell isolation was compared using liver from two marine fish (Sparus aurata and Psetta maxima): (i) two-step collagenase perfusion and (ii) pancreatin digestion with modifications. Cell cultures were incubated in L-15 medium at $17 \pm 1{ }^{\circ} \mathrm{C}$ and monitored for up to six days for cell viability and function using the trypan blue exclusion test, MTT test, lactate dehydrogenase (LDH) activity, and ethoxyresorufin Odeethylase (EROD) activity after Benzo[a]Pyrene exposure. The results showed significant differences between the number of viable cells $(p<0.05)$, the highest number being obtained for the pancreatin digestion method (average $=4.5 \pm 1.9 \times 10^{7}$ cells). Moreover, the hepatocytes showed solid adherence to the culture plate and the rounded shape, changing into a triangular/polygonal shape. The cell viability and function obtained by pancreatin digestion were maintained for five days, and the EROD induction after exposure to the B[a]P showed that cells were metabolically active. This study shows that the optimized pancreatin digestion method is a valid, cost-effective, and simple alternative to the standard perfusion method for the isolation of primary hepatocytes from fish and is suitable for ecotoxicological studies involving marine pollutants, such as PAHs.
\end{abstract}

Keywords: primary hepatocytes; in vitro assays; Sparus aurata

\section{Introduction}

Aquatic ecosystems, from coastline to open ocean, are widely impacted by a countless number of xenobiotics (e.g., heavy metals, persistent organic pollutants (POP), pharmaceuticals (e.g., triclosan), endocrine-disrupting chemicals (EDCs), and plastic wastes and their related chemicals (e.g., BPA, phthalates)) [1-10]. The presence of these xenobiotics in both water and sediments eventually results in ecotoxicological effects in aquatic organisms, from algae to fish $[3,5,6]$. For instance, exposure to polycyclic aromatic hydrocarbons (PAHs), such as Benzo[a]Pyrene (B[a]P), is known to produce carcinogenic effects following bioactivation by cytochrome P450 (CYP) and epoxide hydrolases [4].

Traditionally, in aquatic toxicology, the toxic effect of xenobiotics is mostly evaluated using in vivo models (e.g., algae, such as Pseudokirchneriella subcapitata; invertebrates, such as chironomids or daphnia; and fish, such as rainbow trout, fathead minnow, stickleback, medaka, or zebrafish) [11]. Besides being highly costly and time-consuming, this approach requires a substantial number of animals [12,13], which creates pressure for the replacement, reducing, and refinement (3Rs principle) of in vivo tests, particularly when the research goal is focused on understanding toxicity mechanisms. In this context, in vitro cell cultures 
offer advantages to the in vivo approach, as cells in culture retain the basic characteristics of the in vivo conditions [14,15] while allowing the precise control of physicochemical conditions ( $\mathrm{pH}$, temperature, osmotic pressure, and $\mathrm{O}_{2}$ and $\mathrm{CO}_{2}$ tension) and physiological conditions (such as hormone and nutrient concentrations) of the experiment, reducing the variability of results [15]. Furthermore, the costs and time expended are greatly diminished, as the maintenance of cell cultures is far less demanding than conducting assays with live fish.

The main limitation to the in vitro approach, especially when using immortalized cell lines, is the genetic and phenotypic instability that may introduce variability from one passage to another and the lack of environmental relevance, which compromises the effective extrapolation to whole organisms [16]. However, this can be partially overcome by the usage of freshly isolated primary cultures from species with environmental relevance. These cultures are a mixture of several cell types obtained from a piece of minced or enzymedispersed tissue, thus retaining the characteristics of their source tissue. In particular, in research using hepatocytes, the maintenance of many in vivo characteristics is the most important factor. For instance, Segner and Cravedi [17] found that primary hepatocytes express stable levels of phase I and phase II enzymes, such as CYP1A1, an important factor for studies of metabolically activated contaminants [18-21].

The critical point of using primary hepatocyte cultures is to obtain a viable culture that will survive and be functional long enough for toxicological assessment. The low viability and cell membrane damage associated with simple mechanical or enzymatic digestion methods have discouraged their usage. At the expense of these methods, the collagenase perfusion method became the classic and routinely used method for the isolation of primary hepatocytes by producing a higher number of hepatocytes, which are able to maintain vitality and function for a prolonged period [22]. Two-step collagenase perfusion was originally described by Berry and Friend [22] for the rat liver, but Birnbaum et al. [23] adapted it for the fish liver as well [24]. The authors Baksi and Frazier [22] and Pesonen and Andersson [21] revised the properties and usage of fish primary cell cultures and, even now, a considerable number of studies are still reporting the application of these cultures as a good alternative for the replacement of aquatic organisms [14,19,25-29]. However, most of these studies used freshwater species models, and there is a lack of information regarding the isolation and culture conditions for marine fish hepatocytes. Moreover, perfusion requires skillful handling of procedures, namely in the cannulation step, which may undermine the success of the culture.

Therefore, this study aims to optimize an effective and simple procedure for the isolation and maintenance of viable primary hepatocytes from marine fish, which can be used for ecotoxicological assessment of marine pollutants. To achieve this goal, two marine species with ecological and economic relevance, Sparus aurata and Psetta maxima, were used to isolate primary hepatocytes by two different methods: two-step collagenase perfusion and pancreatin digestion. The viability and functionality of the isolated hepatocytes were assessed under different culture conditions, including 3-(4,5-dimethylthiazol-2-yl)-2,5diphenyltetrazolium bromide (MTT), lactate dehydrogenase (LDH), and ethoxyresorufin O-deethylase (EROD) assays.

\section{Materials and Methods}

\subsection{Fish Acclimatization}

The turbot (Psetta maxima, Linnaeus, 1758) and gilt-headed seabream (Sparus aurata, Linnaeus, 1758) weighing 46.8-75.1 $\mathrm{g}$ and 186.7-271.3 g, respectively, were acquired from a local aquaculture farm (Aquinova-Mira and Setúbal, Portugal, respectively). P. maxima is a bottom-dwelling marine fish, and $S$. aurata is the most economically important pelagic marine sparid fish species cultured along the Mediterranean coast and has been used in ecotoxicological studies [5,6,30-33]. The fish were transported to the MARLab laboratories at the Department of Environmental Sciences and Engineering (FCT NOVA) and maintained in controlled conditions $\left(17 \pm 1{ }^{\circ} \mathrm{C}, 34 \%\right.$ salinity, with a regular photoperiod set at 
$12 \mathrm{~h}$ light/12 $\mathrm{h}$ dark). During this time, the fish were fed with standard commercial chow (as used by the fish supplier) twice a day.

\subsection{Primary Hepatocyte Cell Isolation}

All animals were randomly collected from the tanks, evaluated regarding the general health status, measured for total weight, and irreversibly anesthetized with an aqueous solution of 2-phenoxyethanol (0.25 ppm) [34]. After disinfection with $70 \%$ alcohol, a longitudinal incision from the anus to the gills was performed to expose the liver. Internal organs were observed for their general condition, and fish with excessively fat liver or alterations in tissue consistency were excluded from the procedure.

The primary hepatocytes were isolated using the two-step collagenase perfusion and pancreatin digestion methods, according to Ferreira et al. [19] and Yanhong et al. [24], respectively, with modifications (Figures 1 and 2) as subsequently described. In total, 15 fish were used for both procedures.

\subsubsection{Two-Step Collagenase Perfusion}

A cannula $(24 \mathrm{G})$ was inserted in the portal vein, and the liver was first perfused for 20 min with solution A $\left(176 \mathrm{mM} \mathrm{NaCl}, 4.82 \mathrm{mM} \mathrm{KCl}, 0.44 \mathrm{mM} \mathrm{KH}_{2} \mathrm{PO}_{4}, 3.6 \mathrm{mM}\right.$ $\mathrm{NaHCO}_{3}, 0.35 \mathrm{mM} \mathrm{Na}_{2} \mathrm{HPO}_{4} .2 \mathrm{H}_{2} \mathrm{O}, 10 \mathrm{mM}$ HEPES, $5 \mathrm{mM} \mathrm{Na}_{2}$-EDTA, pH 7.6) at a flow rate of $10 \mathrm{~mL} \mathrm{~min}^{-1}$. The second perfusion step was performed for $15 \mathrm{~min}$ with solution $\mathrm{B}$ (solution A without $\mathrm{Na}_{2}$ EDTA, with $2.5 \mathrm{mM} \mathrm{CaCl}_{2}$ and $0.02 \mathrm{mg} \mathrm{mL}^{-1}$ collagenase IV) at the same flow rate $\left(10 \mathrm{~mL} \mathrm{~min}^{-1}\right)$. Following the two perfusions, the liver was removed and transferred to a chilled dish containing solution C (solution B without collagenase IV and with $1 \% \mathrm{BSA}$ ) for $30 \mathrm{~min}$ and mechanically disrupted by using sterile stainless-steel scissors. The liver fragments were then filtered twice through a stainless-steel 200 and $64 \mu \mathrm{m}$ mesh, and the cells were collected by low-speed centrifugation $(100 \times g, 5 \mathrm{~min}$, $4{ }^{\circ} \mathrm{C}$ ). The cell pellet was washed three times in cooled nonsupplemented Hank's balanced salt solution (HBSS, Lonza) and then resuspended in HBSS medium supplemented with $5 \%$ fetal bovine serum (FBS), penicillin $\left(10 \mathrm{U} \mathrm{mL}^{-1}\right)$, streptomycin $\left(10 \mu \mathrm{g} \mathrm{mL}{ }^{-1}\right)$, and amphotericin $\left(0.025 \mu \mathrm{g} \mathrm{mL}^{-1}\right)$. The cell yield was counted in a Neubauer chamber and their viability was examined by the trypan blue exclusion assay. The percentage of viable cells was calculated as $(\mathrm{A}-\mathrm{B}) / \mathrm{A} \times 100$, with $\mathrm{A}$ being the average of total cells and $\mathrm{B}$ the average of nonviable cells.
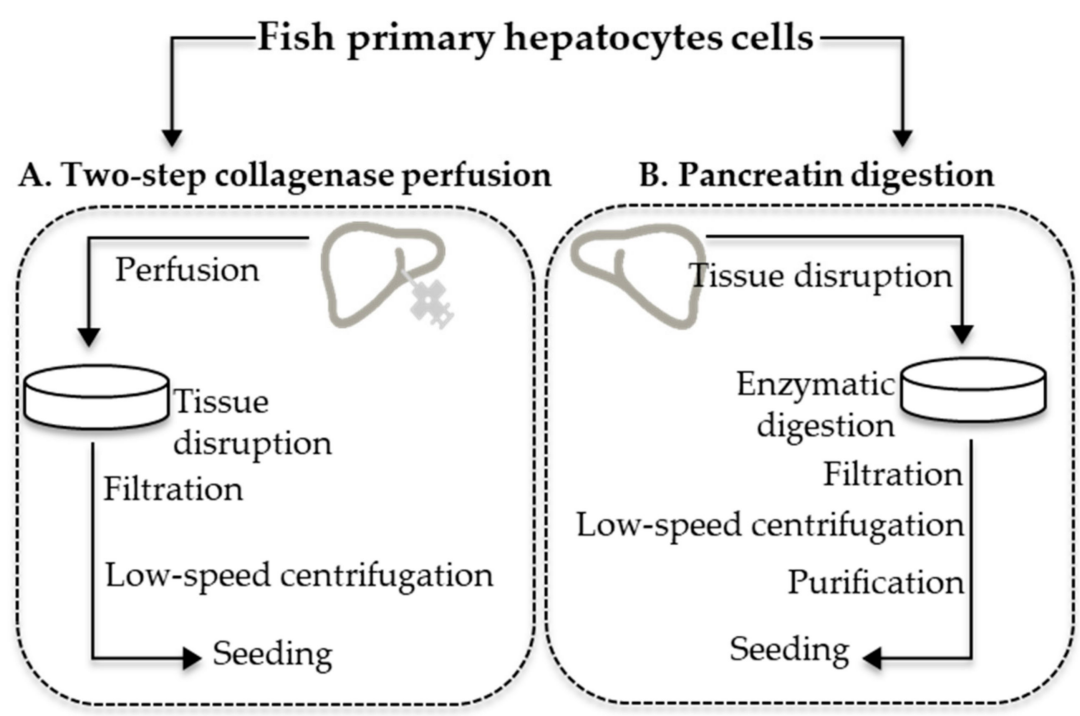

Figure 1. Primary fish hepatocytes isolation methods applied: (A) two-step collagenase perfusion and $(\mathbf{B})$ pancreatin digestion. 


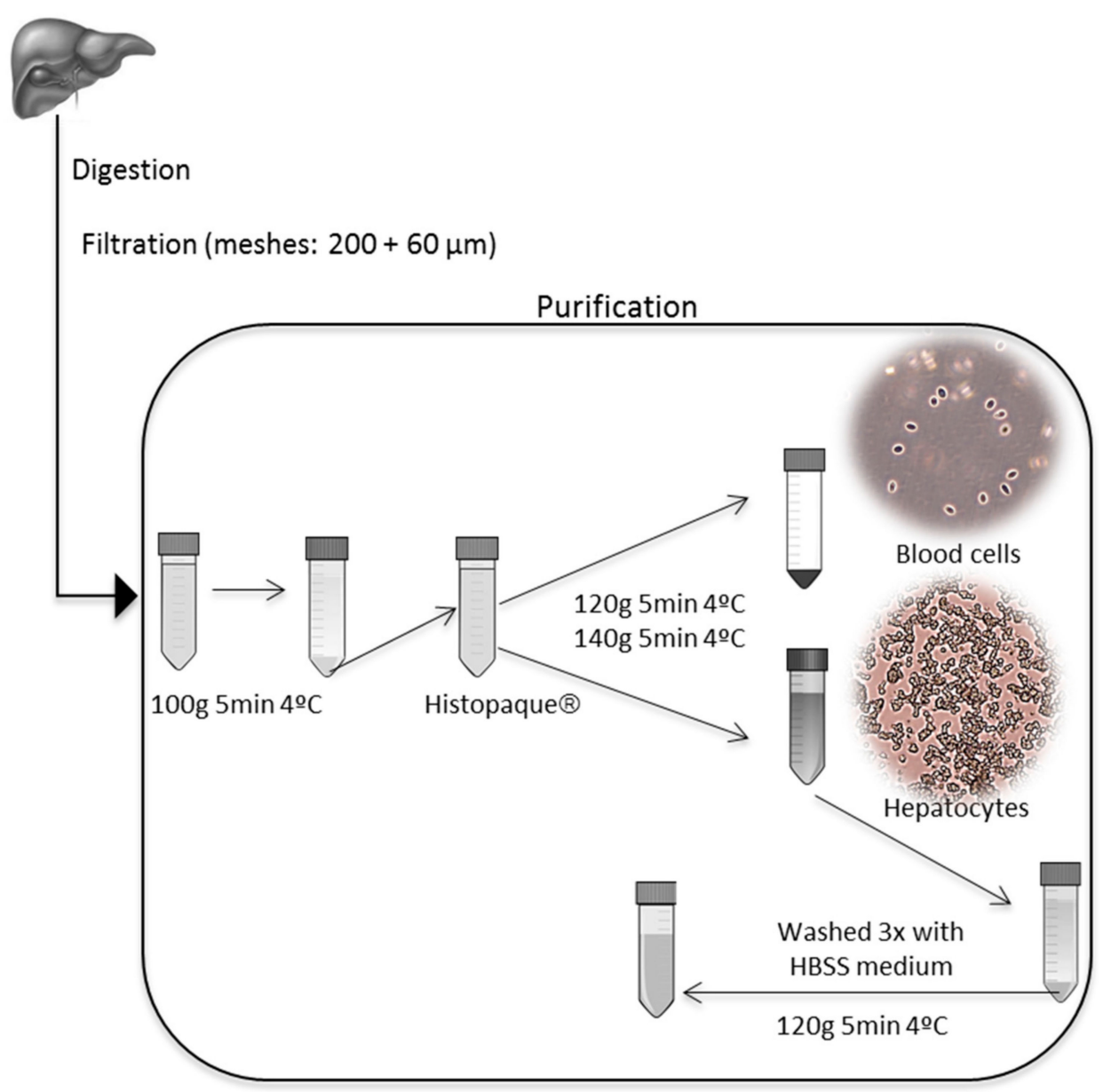

Figure 2. Pancreatin digestion method by Yanhong et al. [24] with modifications to increase culture purity.

After opening the abdomen, the liver was: (A) perfused in situ, digested with collagenase, and disrupted with stainless-steel forceps; (B) cut into small pieces, clipped into fragments, and digested with pancreatin digestive juice. The digested fragments were filtered through stainless-steel meshes $(200 \mu \mathrm{m}$ and $60 \mu \mathrm{m})$, and the cells were collected by low-speed centrifugation $(100 \times g)$.

\subsubsection{Pancreatin Digestion}

The liver was removed from the abdomen, weighed, and placed in a cool dish containing sterile dissection balanced salt solution (DBSS) $(126 \mathrm{mM} \mathrm{NaCl}, 4.82 \mathrm{mM} \mathrm{KCl}$, $1.5 \mathrm{mM} \mathrm{KH}_{2} \mathrm{PO}_{4}, 6.1 \mathrm{mM} \mathrm{Na}_{2} \mathrm{HPO}_{4}, 21.9 \mathrm{mM}$ HEPES, pH 7.4). The liver was then cut into $1.0-2.0 \mathrm{~mm}^{3}$ pieces, washed three times with cool sterile DBSS, and clipped into fragments. The preheated $\left(37^{\circ} \mathrm{C}\right)$ pancreatin digestive juice $(126 \mathrm{mM} \mathrm{NaCl}, 4.82 \mathrm{mM} \mathrm{KCl}, 1.5 \mathrm{mM}$ $\mathrm{KH}_{2} \mathrm{PO}_{4}, 6.1 \mathrm{mM} \mathrm{Na} 2 \mathrm{HPO}_{4}, 0.54 \mathrm{mM} \mathrm{Na}$-EDTA, $0.1 \%$ pancreatin) was added to the dish to digest the fragments for $30 \mathrm{~min}$. During the digestion, the fragments were blown gently with a sterile Pasteur pipette. The digested fragments were then filtered through a stainless-steel mesh ( $200 \mu \mathrm{m}$ and $60 \mu \mathrm{m}$, respectively) and collected by low-speed centrifugation $\left(100 \times g, 5 \mathrm{~min}\right.$, and at $\left.4{ }^{\circ} \mathrm{C}\right)$. The pellet was purified with Histopaque ${ }^{\circledR}$ (Sigma) [35] $\left(120 \times g, 5 \mathrm{~min} 4{ }^{\circ} \mathrm{C}\right.$ and $\left.140 \times g, 5 \operatorname{min~} 4^{\circ} \mathrm{C}\right)$. The hepatocytes were collected from the supernatant, washed three times with nonsupplemented HBSS, and then resuspended in HBSS medium supplemented with $5 \%$ FBS, penicillin $\left(10 \mathrm{U} \mathrm{mL}^{-1}\right)$, streptomycin $\left(10 \mu \mathrm{g} \mathrm{mL}{ }^{-1}\right.$, and amphotericin $\left(0.025 \mu \mathrm{g} \mathrm{mL}^{-1}\right)$. The cell yield was counted in a Neubauer chamber, and viability was examined by the trypan blue exclusion assay. The percentage of viable cells was calculated as described in Section 2.2.1. 


\subsection{Seeding Fish Primary Hepatocytes}

To establish marine fish primary hepatocyte cultures, the isolated hepatocytes showing $\geq 85 \%$ viability [36] were cultured in a complete cell medium consisting of L-15 medium, supplemented with $5 \% \mathrm{FBS}$, penicillin $\left(10 \mathrm{U} \mathrm{mL}^{-1}\right)$, streptomycin $\left(10 \mu \mathrm{g} \mathrm{mL}{ }^{-1}\right)$, and amphotericin $\left(0.025 \mu \mathrm{g} \mathrm{mL}{ }^{-1}\right)$, in 96-well microplates $\left(10^{4}\right.$ cells/well), 24-well microplates $\left(10^{5}\right.$ cells /well), 6 -well microplates $\left(10^{6}\right.$ cells /well), and $35 \mathrm{~mm}$ cell culture dish $\left(10^{6}\right.$ cells/well), with a distinct growth surface coating. The growth surface of each type of plate was previously coated with $0.01 \%$ poly-L-lysine solution (Sigma-Aldrich) and Biocoat Collagen I (Corning). In parallel, plates without treatment were used as controls. The cell cultures were allowed to attach for $24 \mathrm{~h}$ (hereafter defined as $\mathrm{T}_{0}$ cells) and maintained in an incubator at $17 \pm 1{ }^{\circ} \mathrm{C}$ (the fish optimal growth temperatures). The medium was changed every 2 days.

\subsection{Monitoring of Fish Primary Hepatocyte Cultures: Morphology, Viability, and Functionality}

This assessment was performed after $24\left(\mathrm{~T}_{24}\right), 48\left(\mathrm{~T}_{48}\right), 72\left(\mathrm{~T}_{72}\right), 96\left(\mathrm{~T}_{96}\right)$, and $144 \mathrm{~h}$ $\left(\mathrm{T}_{144}\right)$ (6 days) of cell attachment $\left(\mathrm{T}_{0}\right)$, depending on the endpoint.

\subsubsection{Cell Morphology}

Cultured hepatocytes in $35 \mathrm{~mm}$ dish cultures were monitored daily under inverted light microscopy (Olympus) $(10 \times$ and $20 \times$ objectives) to observe the morphological changes over time (i.e., from single rounded cells to aggregate polyhedral morphology typical of hepatocytes) [37].

\subsubsection{Cell Attachment and Viability}

Cell attachment and viability were assessed at $\mathrm{T}_{24}$. Briefly, after the removal of culture media from culture plates $(0.01 \%$ poly-L lysine, collagen I, and without coating), the primary hepatocytes were washed with sterile $1 \times$ PBS and detached with trypsin $(0.25 \%$ trypsin-EDTA, Sigma). Cell detachment was observed under the microscope and an aliquot $(50 \mu \mathrm{L})$ of the cell suspension was taken, and cells were counted in a Neubauer chamber by the trypan blue exclusion assay. Cell viability was expressed relative to the $T_{0}$ cell number.

\subsubsection{Cell Viability by MTT}

The MTT assay was performed using cell cultures at $\mathrm{T}_{0}, \mathrm{~T}_{24}, \mathrm{~T}_{48}, \mathrm{~T}_{72}, \mathrm{~T}_{96}$, and $\mathrm{T}_{144}$ and according to the methodology described by Mosmann and modified by Carvalho et al. [38,39]. Briefly, the MTT solution (at a final concentration of $400 \mu \mathrm{g} \mathrm{mL} \mathrm{mL}^{-1}$ per well) was added to 96-well plates prepared previously with 104 cells/well followed by incubation at 16 or $18{ }^{\circ} \mathrm{C}$ (depending on fish species) for $4 \mathrm{~h}$. Following the incubation period, the medium with the MTT was removed and the formazan crystals dissolved using a $150 \mu \mathrm{L} /$ well 4:1 mixture of dimethyl sulfoxide (DMSO)/glycine buffer (50 mM glycine, $50 \mathrm{mM}$ sodium chloride/ $\mathrm{NaOH}, \mathrm{pH} 10.5$ ) by shaking for $20 \mathrm{~min}$ at $200 \mathrm{rpm}$. The absorbance was measured at $550 \mathrm{~nm}$ on a microplate reader. Cell viability was expressed as the percentage of $T_{0}$ cells.

\subsubsection{Detection of LDH in the Supernatant}

Lactate dehydrogenase (LDH) release was used as an indicator of hepatocyte mortality. This assay was performed using the culture medium collected at $\mathrm{T}_{0}, \mathrm{~T}_{24}, \mathrm{~T}_{48}, \mathrm{~T}_{72}, \mathrm{~T}_{96}$, and $\mathrm{T}_{114}$. After the collection of the medium from 24 -well plates previously cultured with $10^{5}$ cells/well, the medium was centrifuged at $4{ }^{\circ} \mathrm{C}$ for $10 \mathrm{~min}(12,000 \mathrm{~g})$ to remove floating cells. The LDH activity was measured using the Pierce LDH cytotoxicity assay kit (Thermo Scientific, USA), according to the manufacturer's instructions. The absorbance of each sample was read at $490 \mathrm{~nm}$ and $680 \mathrm{~nm}$ using a microplate reader. A positive LDH control (from the kit) and negative control (L-15 medium without cells) controls were run in parallel. 


\subsubsection{Ethoxyresorufin O-Deethylase (EROD) Activity}

EROD (CYP1A) activity was measured according to the method adopted for the 24-well plate described by Ferreira et al. [18]. Briefly, after $24 \mathrm{~h}$ and $48 \mathrm{~h}$ of exposure to $0.1 \mu \mathrm{M}, 0.5 \mu \mathrm{M}$, and $1 \mu \mathrm{M} \mathrm{B}[\mathrm{a}] \mathrm{P}$, the medium was removed, and the cells washed once with cold PBS. EROD activity was measured by adding a EROD reaction mixture containing $1 \mathrm{mg} / \mathrm{mL}$ BSA, $5 \mu \mathrm{M}$ 7-ethoxyresorufin (7-ER), and $0.5 \mathrm{mM} \mathrm{NADPH}$ and incubated for $30 \mathrm{~min}$ in the dark at $37 \pm 1^{\circ} \mathrm{C}$. Fluorescence was measured at $560 \mathrm{~nm}$ excitation and $610 \mathrm{~nm}$ emission. EROD activity was calculated based on the resorufin standard curve obtained for each independent experiment. After EROD measurement, total protein concentration was determined in the same well by the Bradford method with BSA as a standard.

\subsection{Data Analysis}

Statistical significance of results was evaluated with the software Statistica 8.0 Statsoft, 2007 (Tulsa, USA) by applying the nonparametric Mann-Whitney $U$ test to compare two independent variables or the parametric $t$-test for independent variables, depending on the observation of parametric test assumptions, i.e., normality of distribution (Shapiro-Wilk's test) and homogeneity of variances (Levene's test). All data were expressed as means $\pm \mathrm{SE}$ of more than three independent experiments, and statistical differences were established as significant at $p<0.05$ and very significant $p<0.01$.

\section{Results}

\subsection{Cell Yield and Viability}

The cell yield obtained from S. aurata liver ranged from $1.04 \times 10^{7}$ to $2.47 \times 10^{7}$ for the two-step collagenase perfusion method and $3.3 \times 10^{7}$ to $7.31 \times 10^{7}$ for the pancreatin digestion method (Table 1), and the cell viability ranged from 70.7 to $72.8 \%$ for the two-step collagenase perfusion method and $95.1 \%$ to $100 \%$ for the pancreatin digestion method (Table 1). The cell yield obtained for P. maxima liver by pancreatin digestion ranged from $1.08 \times 10^{7}$ to $3.44 \times 10^{7}$ (Table 1 ). The small size of livers (average $=0.47 \pm 0.19 \mathrm{~g}$ ) made it difficult to perform the two-step collagenase perfusion method in this species.

Table 1. Total number of primary hepatocyte cells (range and average) isolated from the liver of $S$. aurata and P. maxima fish obtained by different cell isolation methods, two-step collagenase perfusion and pancreatin digestion, and their respective cell viability (\%).

\begin{tabular}{|c|c|c|c|c|c|}
\hline \multirow{2}{*}{ Method } & \multirow{2}{*}{ Fish Species } & \multicolumn{2}{|c|}{ Weight (g) } & \multirow{2}{*}{$\begin{array}{c}{ }^{1} \text { Number of Cells } \\
\left(\times 10^{7}\right)\end{array}$} & \multirow{2}{*}{$\%$ of Viability } \\
\hline & & Fish & Liver & & \\
\hline $\begin{array}{l}\text { Two-step } \\
\text { perfusion }\end{array}$ & Sparus aurata & $234 \pm 43.3$ & $4.80 \pm 1.66$ & $\begin{array}{c}1.04-2.47 \\
\bar{x}=1.91 \pm 0.77^{\mathrm{a}}\end{array}$ & $70.7-72.8$ \\
\hline \multirow{2}{*}{$\begin{array}{l}\text { Pancreatin } \\
\text { digestion }\end{array}$} & Sparus aurata & $236 \pm 41.2$ & $4.47 \pm 1.37$ & $\begin{array}{c}3.3-7.31 \\
\bar{x}=4.5 \pm 1.9^{b}\end{array}$ & $95.1-100$ \\
\hline & Psetta maxima & $62.5 \pm 8.57$ & $0.47 \pm 0.19$ & $\begin{aligned} & 1.08-3.44 \\
\bar{x}= & 1.97 \pm 0.76^{\mathrm{c}}\end{aligned}$ & 100 \\
\hline
\end{tabular}

${ }^{1}$ Range of cell yields and the respective average of $3^{\mathrm{a}}, 4^{\mathrm{b}}$, and $8^{\mathrm{c}}$ independent assays.

The recommended work viability is $\geq 85 \%$ [36]. For pancreatin digestion, the viability was $\geq 95 \%$, which is in good agreement with other results (>98.4\%) [24]. This high viability is related to the lower concentration of pancreatin used, which should cause fewer injuries to isolated hepatocytes [24]. The viability achieved with two-step collagenase perfusion was below $85 \%(\max 73 \%)$, which is likely related to the long-time involved in the cannulation procedure and also needs accurate technical skills. Based on the viability and cell yield results, we proceeded with the pancreatin digestion method in $S$. aurata in subsequent experiments. 


\section{Cell Culture Purity}

The presence of blood cells and tissue debris was observed in the first extractions with the pancreatin digestion method. To improve the culture purity, we applied some modifications to the original pancreatin digestion method described by Yanhong et al. [23]. As mentioned in Section 2.2.2, these modifications included the usage of two meshes (200 and $60 \mu \mathrm{m}$ ) during the filtration process and two centrifugation steps with Histopaque ${ }^{\circledR}$ (Figure 2). The usage of these two meshes improved the removal of tissue debris, and the two subsequent centrifugations $\left(120 \times g\right.$ and $140 \times g, 5$ min at $\left.4{ }^{\circ} \mathrm{C}\right)$ with Histopaque ${ }^{\circledR}$ improved the removal of blood cells from the cell culture (Figure 2). The presence of blood cells in the resulting culture is a critical point. In the two-step perfusion method, the perfusion step aims to clean up the liver from these cells. However, several authors have suggested the low-speed centrifugation with Percoll gradient as an alternative to guarantee a pure culture of hepatocytes [24,40,41]. Taking this into account, we combined enzymatic-based dissociation with the Percoll gradient purification, using Histopaque ${ }^{\circledR}$ to obtain a high-purity culture. Histopaque ${ }^{\circledR}$ is a solution of polysucrose and sodium diatrizoate, adjusted to a density of $1.077 \mathrm{~g} / \mathrm{mL}$, which is commonly used in isolation and purification of blood cells [35,42]. This proved to be an adequate substitute for the perfusion method, greatly simplifying procedures.

In most cases, after this purification process, the hepatocyte culture purity was $100 \%$, as determined by microscopic observation. The three final washing steps further improved the removal of dead cells.

\subsection{Cell Culture Condition: Morphology, Viability, and Function}

The marine fish primary hepatocyte cultures obtained by the optimized pancreatin digestion method are presented in Figure 3 . The culture shows $\geq 85 \%$ viability and $100 \%$ hepatocyte purity. The monitoring data at $\mathrm{T}_{0}$ to $\mathrm{T}_{144}$ showed that the cells were attached to a plate coated with the poly-L lysine and collagenase I coated-plate.

Immediately upon isolation, hepatocytes were seen as single separated cells, which were showing a rounded shape (Figure 3A). Twenty-four hours after isolation, and after $24 \mathrm{~h}$ to allow cell attachment, this initial rounded shape was changed into a triangular/polygons shape, some hepatocytes began to flatten, and the cell-cell contact was evident (Figure 3B). After $48 \mathrm{~h}$ in culture, cells were clustering into small groups (Figure 3C), and larger clusters were observed after $72 \mathrm{~h}$, with the subsequent loss of the initial rounded appearance as the boundaries between the cells increased (Figure 3D).

Primary hepatocytes' viability was assessed by the trypan blue exclusion and MTT assays. The trypan blue exclusion was performed at $\mathrm{T}_{24}$, and the results showed cell viability of $94.8 \pm 14.1 \%$ for the collagen I plate and $98.1 \pm 11.5$ for the poly-L lysine plate (Table 2). The MTT viability test was performed at $\mathrm{T}_{24}, \mathrm{~T}_{48}$, and $\mathrm{T}_{72}$. Comparing the results for plates coated with collagen I, the viability decreased slightly, reaching a minimum of the viability of $78.7 \pm 0.47 \%$ at $\mathrm{T}_{72}$ (Table 2). Interestingly, no significant differences in cell viability were obtained when comparing the manual poly-L-lysine coating and commercial collagen I coating plates (Table 2).

The assessment of LDH release was performed in cell culture media and collected after $\mathrm{T}_{24}, \mathrm{~T}_{48}$, and $\mathrm{T}_{144}$. Analysis of the culture supernatants showed that $\mathrm{LDH}$ secretion increased gradually over time, with a peak at $\mathrm{T}_{144}$ (Figure 4 ). 

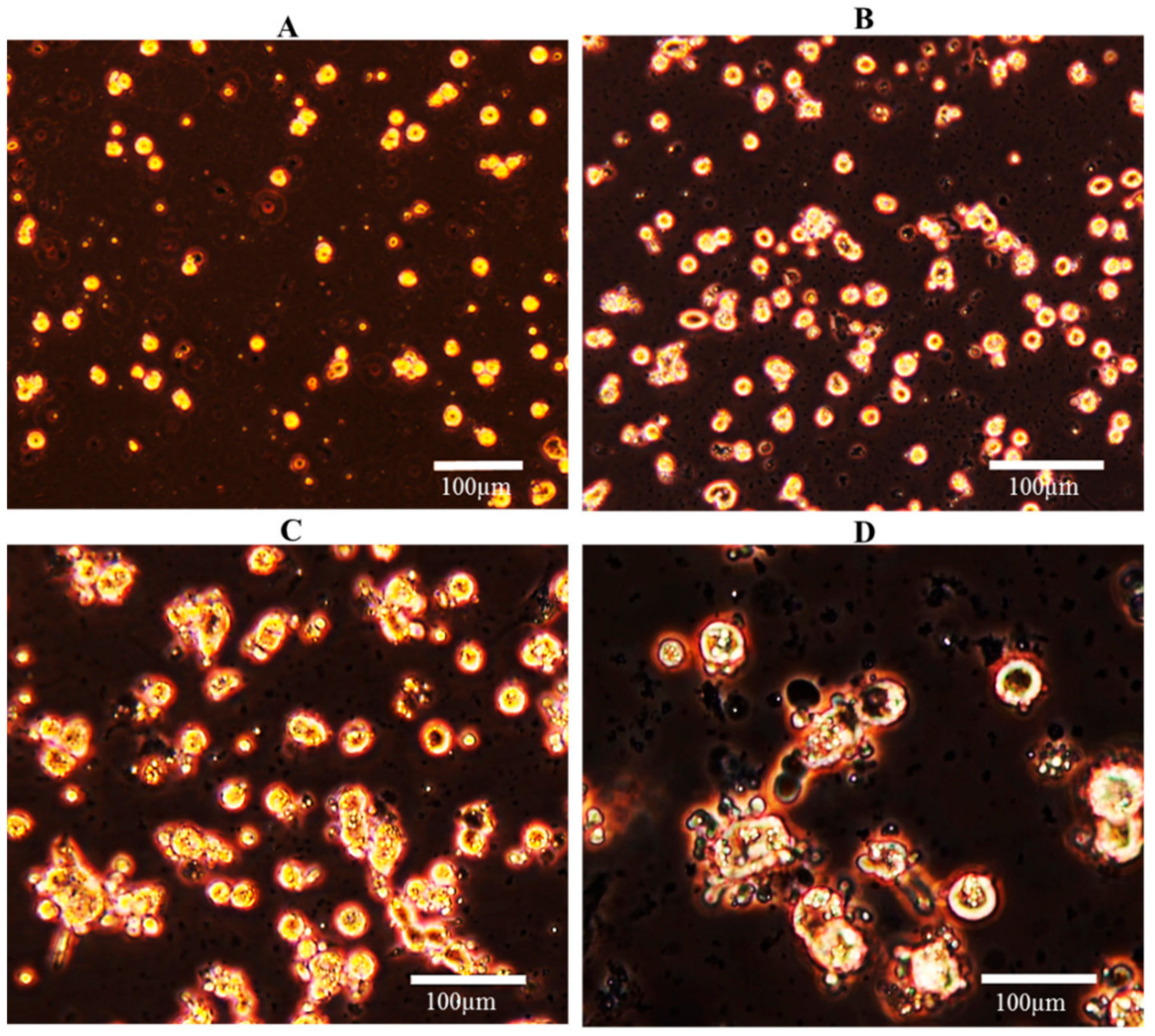

Figure 3. Culture of $S$. aurata primary hepatocytes isolated by pancreatin digestion with modifications (A) and after incubation in poly-L lysine-coated plates up to 24 (B), 48 (C), and $72 \mathrm{~h}$ (D). The observations were made under inverted light microscopy (Olympus) with a $10 \times$ objective $(\mathbf{A}, \mathbf{B})$ and a $20 \times$ objective $(\mathbf{C}, \mathbf{D})$.

Table 2. The viability of primary hepatocytes isolated by pancreatin digestion after $\mathrm{T}_{24}, \mathrm{~T}_{48}$, and $\mathrm{T}_{72}$ in culture with different plates, no-treatment, and coated with the poly-L-lysine solution (Sigma) and collagen I (Sigma). Cell viability was evaluated by trypan blue assay (TBA) and MTT. All the data are expressed as $\%$ of $\mathrm{T}_{0}$ and are expressed as the mean $\pm \mathrm{SD}$ of more than 3 independent isolations. Significant differences from the $\mathrm{T}_{0}$ was observed for the plates coated; ${ }^{*} p<0.05$.

\begin{tabular}{ccc}
\hline \multirow{2}{*}{ Viability Tests } & \multicolumn{2}{c}{ Plate Coating } \\
\cline { 2 - 3 } & Plate Coated w/Poly-L Lysine & Plate Coated w/Collagen I \\
\hline TBA $(24 \mathrm{~h})$ & $98.1 \pm 11.5$ & $94.6 \pm 14.1$ \\
LDH $(24 \mathrm{~h})$ & $97.5 \pm 3.4$ & $95.5 \pm 4.9$ \\
\hline \multicolumn{3}{c}{ MTT } \\
\hline $48 \mathrm{~h}$ & $84.1 \pm 8.13^{*}$ & $91.8 \pm 2.73$ \\
$72 \mathrm{~h}$ & $82.7 \pm 4.157^{*}$ & $89.0 \pm 2.93^{*}$ \\
\hline
\end{tabular}




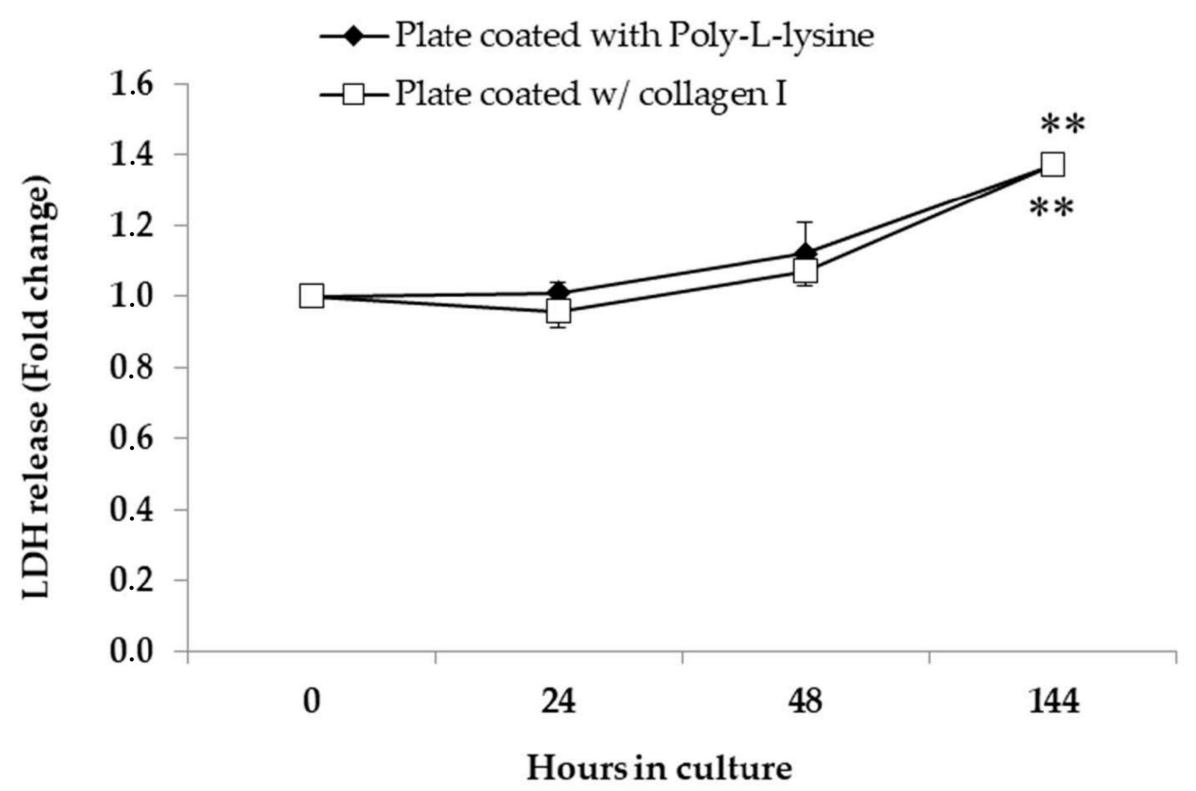

Figure 4. Lactate dehydrogenase (LDH) released by S. aurata primary hepatocytes cultured in a 24well plate coated with poly-L-lysine and collagen I. After the overnight incubation of $10^{5}$ cells/well, the L-15 medium was collected at 24,48 , and $144 \mathrm{~h}$ to assess LDH activity. A significant difference was observed between the control and $\mathrm{T}_{144} ;{ }^{* *} p<0.01$.

To assess cellular function, namely xenobiotic phase I metabolism, primary hepatocytes of S. aurata cultured on the poly-L-lysine plates were exposed to $0.1,0.5$, and $1 \mu \mathrm{M}$ of B[a]P to assess CYPA1 activity via EROD-based assay (Figure 5). The results showed a significant increase of EROD activity at $\mathrm{T}_{24}$ and $\mathrm{T}_{48}$, relative to control cells $(p<0.05)$.

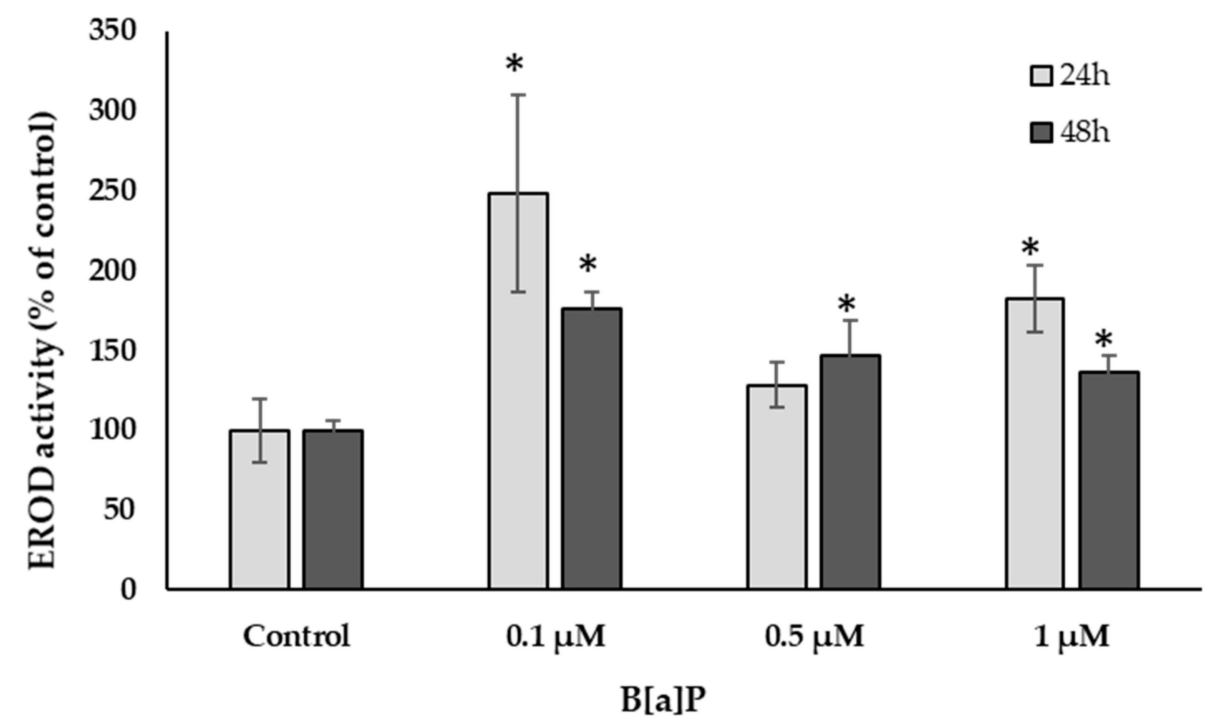

Figure 5. EROD activity of $S$. aurata primary hepatocytes exposed to different concentrations of Benzo(a)pyrene (B[a]P) for 24 and 48 h. Ethoxyresorufin O-Deethylase (EROD) activity is expressed relative to control cells (DMSO). Values are mean \pm SE of 4 to 5 independent extractions. A significant difference was observed between the control and $\mathrm{T}_{24}$ and $\mathrm{T}_{48} ;{ }^{*} p<0.05$.

\section{Discussion}

The use of primary cells carries several challenges, including (1) the process of cell isolation, (2) the maintenance of viable and functional cells in culture, and (3) reproducibility $[43,44]$. Among these, the most critical challenge is to have an optimized isolation 
method adjusted to the demands of the investigation. Among the available methodologies, two methods were used to obtain primary hepatocytes culture from marine fish: the twostep collagenase perfusion and a common enzymatic-based dissociation by a pancreatic enzyme. Two-step collagenase perfusion combines the perfusion technique with the dissociation action of collagenase and has been successfully used to isolate primary hepatocytes for toxicological evaluation of aquatic xenobiotics purposes [14,19,45-53].

Although enzymatic dissociation methods are not so commonly used, the pancreatin digestion method described in the present research (Figures 1 and 2) proved to be effective to isolate marine fish primary hepatocytes in terms of (1) its applicability for small/medium/large fish, (2) low cost and simple procedure, and (3) high cell yield and viability achieved (Table 1). In comparison with the two-step collagenase perfusion method, the pancreatin method proved to be very versatile, being suitable for extracting cells from smaller livers where it is difficult or impossible to apply the liver cannulation procedure, required for the two-step collagenase perfusion method. Enzymatic digestion is in general a better alternative when the model in the study is small, such as the case of zebrafish [54].

Besides these advantages, pancreatin digestion also proved to be more effective in obtaining a significantly higher number of viable cells in comparison with those obtained by the two-step collagenase perfusion method (Table 1). Using healthy S. aurata livers of a similar weight $(p>0.05)$, the number of viable cells obtained by pancreatin digestion was up to four-fold higher than by collagenase perfusion. Additionally, the percentage of viable cells extracted using pancreatin digestion was 30\% higher than with the two-step collagenase perfusion method. This is extremely important since obtaining a high number of viable cells is the first critical point of using primary cells.

After isolation, primary cells must remain viable and functional long enough to allow successive experiments. Thus, the viability of the isolated primary hepatocytes was monitored over two to six days in culture by several tests (trypan blue exclusion test, MTT assay, and LDH release). All these assays showed a similar result (Table 2); however, MTT and LDH data had a smaller standard error, suggesting that these tests may be a more reproducible method than trypan blue exclusion by eliminating error associated with cell counting. In general, until $72 \mathrm{~h}$ in culture (three days after the isolation), the viability of primary hepatocytes plated in coated plates was on average $>80 \%$ (Table 2). This suggests that when seeded in coated plates, either with the commercial collagen or manually with poly-L lysine, after the initial attachment, the majority of cells remain viable and stable. Furthermore, the results of the LDH release test, used to assess cell death, showed that the cells remain viable and functional for six days. Indeed, a significant increase in cell death $(\mathrm{p}<0.01)$ was only observable after six days in culture (Figure 4$)$. This result agrees with other studies, which showed a viability $>85 \%$ after the first five days in culture and a significant decline for longer periods [14].

Freshwater species (such as Oncorhynchus mykiss, Cyprinus carpio, Oreochromis niloticus Pelteobagrus fulvidraco, and Ctenopharyngodon idellus) are the most used fish models to assess the mode of action of environmental pollutants [14,45,46,48,51,55-59]. However, in the context of marine environmental toxicology, marine fish primary hepatocytes are an interesting approach when assessing the effects of xenobiotics, such as polycyclic aromatic hydrocarbons (PAHs), since it increases the ecological and economic relevance to the studies. Among PAHs, $\mathrm{B}[\mathrm{a}] \mathrm{P}$ is a five-ring $\mathrm{PAH}$ that can be found in aquatic environments [8] and is a potent CYP1A1 inducer $[4,19,30,60]$. The CYP1A mediated activation of $\mathrm{B}[\mathrm{a}] \mathrm{P}$ produces DNA reactive intermediates, such as $\mathrm{B}[\mathrm{a}] \mathrm{P}-7,8$-diol-9,10-epoxide, which can form stable DNA adducts $[4,60]$.

Several studies have already demonstrated the toxicological response of $S$. aurata towards B[a]P exposure [30-33], including the induction of EROD activity in fish both for in vivo and in vitro models $[4,19,30,60,61]$. To verify the metabolic activity of primary hepatocytes obtained from $S$. aurata liver by the pancreatin digestion method, the ERODbased assay was used after cell exposure to B[a]P. In fact, after 24 and $48 \mathrm{~h}$ of exposure to three different concentrations of $\mathrm{B}[\mathrm{a}] \mathrm{P}(0.1,0.5$, and $1 \mu \mathrm{M})$, EROD activity increased 
significantly relative to control cells, showing that $S$. aurata primary cells were active and able to metabolize this xenobiotic by liver cytochrome P450 dependent-monooxygenases.

A nondependent dose-response and higher EROD activity being obtained at the lowest $\mathrm{B}[\mathrm{a}] \mathrm{P}$ concentration tested was also observed. This pattern has already been verified by Wessel et al. [61], who reported similar results for sole hepatocytes exposed to $0.1,0.5$, 1,5 , and $25 \mu \mathrm{M}$ B[a]P concentrations. In contrast, Ferreira et al. [19], who used primary hepatocytes isolated from Dicentrarchus labrax, reported a dose-response result for EROD activity with a peak at a $1 \mu \mathrm{M} \mathrm{B}[\mathrm{a}] \mathrm{P}$ concentration (maximum studied concentration). However, the CYP1A1 response of fish to contaminants is known to be species specific [61]. Comparing the two exposure times, EROD activity was higher after $24 \mathrm{~h}$ of exposure than $48 \mathrm{~h}$. This observation is in line with previous studies that reported a peak of EROD activity after $24 \mathrm{~h}$ of exposure of $S$. aurata treated with $20 \mathrm{mg} / \mathrm{Kg}$ of intraperitoneal B[a]P injections [30].

\section{Conclusions}

This study presented an optimized methodology for the isolation of marine fish primary hepatocytes, which can be maintained viable and functional for up to five days, an essential feature for using primary cultures in ecotoxicity testing. This optimized protocol for pancreatin digestion, besides being a good alternative to the commonly used perfusion method, proved to be a suitable method to be used in future ecotoxicological studies involving marine pollutants, such as PAHs. This is particularly relevant in the present-day context, where compound mixtures in the aquatic environment are abundant, therefore demanding fast and thorough analysis of toxicity mechanisms, using alternatives to in vivo models as stated in the 3Rs principle.

Author Contributions: Conceptualization, N.F. and M.M.; formal analysis, N.F., B.M., V.B., and M.M.; funding acquisition, M.M.; investigation, N.F. and B.M.; methodology, N.F., B.M., and M.D.; supervision, V.B. and M.M.; writing — original draft preparation, N.F.; writing—review and editing, N.F., B.M., V.B., M.D., and M.M. All authors have read and agreed to the published version of the manuscript.

Funding: This work was supported by the Project PAHMIX-Mixtures of Environmental Carcinogens: a molecular approach to improve environmental risk assessment strategies (PTDC/CTAAMB/29173/2017), by the Marine and Environmental Sciences Centre-MARE (UIDB04292/2020; UIDP/04292/2020), by the Applied Molecular Biosciences Unit-UCIBIO (UIDB04378/2020; UIDP/ 04378/2020) and by iMed. ULisboa's Strategic Project (UIDB/04138/2020; UIDP/04138/ 2020) all financed by national funds from Fundação para a Ciência e Tecnologia (FCT; www.fct.pt). Neusa Figueiredo is financed by FCT via PAHMIX project (PTDC/CTA-AMB/29173/2017, NOVAID39). Beatriz Matos is financed by FCT via PhD grant 2020.09005. BD. Vasco Branco is financed by national funds via FCT through Norma Transitória-DL57/2016/CP1376/CT002. Marta Martins is financed through FCT—Fundação para a Ciência e a Tecnologia, I.P., under the Scientific Employment Stimulus-Institutional Call (CEECINST/00102/2018).

Institutional Review Board Statement: Ethical review and approval were waived for this study, due to the absence of experiments with live animals. Only primary cells were collected from fish using humane procedures performed by FELASA category $\mathrm{C}$ certified researchers, which are authors of this manuscript (M.M. and M.D.). Housing of fish took place in certified fish facilities approved by the apropriate Portuguese authority, Direção Geral da Alimentação e Veterinária (ref: 0421/000/000/2013).

Informed Consent Statement: Not applicable.

Data Availability Statement: The data presented in this study are available on request from the corresponding author.

Acknowledgments: The authors' acknowledge Joana Antunes and Joana Neves for their support in the maintenance of fish in controlled and certified wet rooms at MARE-FCT NOVA.

Conflicts of Interest: The authors declare no conflict of interest. 


\section{References}

1. Antunes, J.; Frias, J.; Sobral, P. Microplastics on the Portuguese coast. Mar. Pollut. Bull. 2018, 131, 294-302. [CrossRef]

2. Karri, V.; Kumar, V.; Ramos, D.; Oliveira, E.; Schuhmacher, M. Comparative in vitro toxicity evaluation of heavy metals (lead, cadmium, arsenic, and methylmercury) on HT-22 hippocampal cell line. Biol. Trace Elem. Res. 2018, 184, 226-239. [CrossRef] [PubMed]

3. IPEN and the National Toxics Network (NTN). Ocean Pollutants Guide: Toxic Threats to Human and Marine Life. 2018. Available online: www.ipen.org (accessed on 25 June 2019).

4. Martins, M.; Silva, A.; Costa, M.H.; Miguel, C.; Costa, P. Co-exposure to environmental carcinogens in vivo induces neoplasiarelated hallmarks in low genotoxicity events, even after removal of insult. Sci. Rep. 2018, 8, 3649. [CrossRef]

5. Martins, M.; Ferreira, A.M.; Costa, M.H.; Costa, P.M. Comparing the genotoxicity of a potentially carcinogenic and a noncarcinogenic PAH, singly, and in binary combination, on peripheral blood cells of the European sea bass. Environ. Toxicol. 2016, 31, 1307-1318. [CrossRef] [PubMed]

6. Martins, M.; Santos, J.M.; Diniz, M.S.; Ferreira, A.M.; Costa, M.H.; Costa, P.M. Effects of carcinogenic versus non-carcinogenic AHR-active PAHs and their mixtures: Lessons from ecological relevance. Environ. Res. 2015, 138, 101-111. [CrossRef] [PubMed]

7. Martins, M.; Costa, P.M.; Ferreira, A.M.; Costa, M.H. Comparative DNA damage and oxidative effects of carcinogenic and non-carcinogenic sediment-bound PAHs in the gills of a bivalve. Aquat. Toxicol. 2013, 142-143, 85-95. [CrossRef] [PubMed]

8. Martins, M.; Costa, P.M.; Raimundo, J.; Vale, C.; Ferreira, A.M.; Costa, M.H. Impact of remobilized contaminants in Mytilus edulis during dredging operations in a harbour area: Bioaccumulation and biomarker responses. Ecotoxicol. Environ. Saf. 2012, 85, 96-103. [CrossRef]

9. Martins, M.; Ferreira, A.M.; Vale, C. The influence of Sarcocornia fruticosa on retention of PAHs in salt marsh sediments (Sado estuary, Portugal). Chemosphere 2008, 71, 1599-1606. [CrossRef] [PubMed]

10. Tasca, A.L.; Fletcher, A. State of the art of the environmental behaviour and removal techniques of the endocrine disruptor 3,4-dichloroaniline. J. Environ. Sci. Health A Tox. Hazard Subst. Environ. Eng. 2018, 53, 260-270. [CrossRef]

11. Celandar, M.C. Cocktail effects on biomarker responses in fish. Aquat. Toxicol. 2011, 105, 72-77. [CrossRef]

12. Tan, L.; Schirmer, K. Cell culture-based biosensing techniques for detecting toxicity in water. Curr. Opin. Biotechnol. 2017, 45, 59-68. [CrossRef] [PubMed]

13. Kramer, N.I.; Hermens, J.L.M.; Schirmer, K. The influence of modes of action and physicochemical properties of chemicals on the correlation between in vitro and acute fish toxicity data. Toxicol. Vitro. 2009, 23, 1372-1379. [CrossRef]

14. Bickley, L.K.; Langea, A.; Winterb, M.J.; Tylera, C.R. Evaluation of a carp primary hepatocyte culture system for screening chemicals for oestrogenic activity. Aquat. Toxicol. 2009, 94, 195-203. [CrossRef]

15. Baksi, S.M.; Frazier, J.M. Isolated fish hepatocytes- model systems for toxicology research. Aquat. Toxicol. 1990, 16, 229-256. [CrossRef]

16. Poteser, M. Cell-based in vitro models in environmental toxicology: A review. Biomonitoring 2017, 4, 11-26. [CrossRef]

17. Segner, H.; Cravedi, J.P. Metabolic activity in primary cultures of fish hepatocytes. Altern. Lab. Anim. 2001, 29, 251-257. [CrossRef] [PubMed]

18. Rodd, A.L.; Messier, N.J.; Vaslet, C.A.; Kane, A.B. A 3D fish liver model for aquatic toxicology: Morphological changes and Cyp1a induction in PLHC-1 microtissues after repeated benzo(a)pyrene exposures. Aquat. Toxicol. 2017, 186, 134-144. [CrossRef]

19. Ferreira, M.; Santos, P.; Rey-Salgueiro, L.; Zaja, R.; Reis-Henriques, M.A.; Smital, T. The first demonstration of CYP1A and the ABC protein(s) gene expression and activity in European seabass (Dicentrarchus labrax) primary hepatocytes. Chemosphere 2014, 100, 152-159. [CrossRef]

20. Lakra, W.S.; Raja Swaminathan, T.; Joy, K.P. Development, characterization, conservation and storage of fish cell lines: A review. Fish Physiol. Biochem. 2011, 37, 1-20. [CrossRef]

21. Pesonen, M.; Andersson, T.B. Fish primary hepatocyte culture; an important model for xenobiotic metabolism and toxicity studies. Aquat. Toxicol. 1997, 37, 253-267. [CrossRef]

22. Berry, M.N.; Friend, D.S. High-yield preparation of isolated rat liver parenchymal cells. J. Cell Biol. 1969, 43, 506-520. [CrossRef] [PubMed]

23. Birnbaum, M.J.; Schulta, J.; Fain, J.N. Hormone-stimulated glycogenolysis in isolated goldfish hepatocytes. Am. J. Physiol. 1976, 231, 191-197. [CrossRef] [PubMed]

24. Yanhong, F.; Chenghua, H.; Guofang, L.; Haibin, Z. Optimization of the isolation and cultivation of Cyprinus carpio primary hepatocytes. Cytotechnology 2008, 58, 85-92. [CrossRef]

25. Bermejo-Nogales, A.; Connolly, M.; Rosenkranz, P.; Fernández-Cruz, M.L.; Navas, J.M. Negligible cytotoxicity induced by different titanium dioxide nanoparticles in fish cell lines. Ecotoxicol. Environ. Saf. 2017, 138, 309-319. [CrossRef] [PubMed]

26. Petersen, K.; Hultman, M.T.; Tollefsen, K.E. Primary hepatocytes from Arctic char (Salvelinus alpinus) as a relevant Arctic in vitro model for screening contaminants and environmental extracts. Aquat. Toxicol. 2017, 187, 141-152. [CrossRef]

27. Stott, L.C.; Schnell, S.; Hogstrand, C.; Owen, S.F.; Bury, N.R. A primary fish gill cell culture model to assess pharmaceutical uptake and efflux: Evidence for passive and facilitated transport. Aquat. Toxicol. 2015, 159, 127-137. [CrossRef]

28. Bury, N.R.; Schnell, S.; Hogstrand, C. Gill cell culture systems as models for aquatic environmental monitoring. J. Exp. Biol. 2014, 217, 639-650. [CrossRef] 
29. Thomas, K.V.; Farkas, J.; Farmen, E.; Christian, P.; Langford, K.; Wu, Q.; Tollefsen, K.E. Effects of dispersed aggregates of carbon and titanium dioxide engineered nanoparticles on rainbow trout hepatocytes. J. Toxicol. Environ. Health A 2011, 74, $466-477$. [CrossRef]

30. Banni, M.; Bouraoui, Z.; Ghedira, J.; Clerandeau, C.; Guerbej, H.; Narbonne, J.F.; Boussetta, H. Acute effects of benzo[a]pyrene on liver phase I and II enzymes, and DNA damage on sea bream Sparus aurata. Fish Physiol. Biochem. 2009, 35, 293-299. [CrossRef]

31. Santacroce, M.P.; Pastore, A.S.; Tinelli, A.; Colamonaco, M.; Crescenzo, G. Implications for Chronic Toxicity of Benzo[a]Pyrene in Sea Bream Cultured Hepatocytes: Cytotoxicity, Inflammation, and Cancerogenesis. Environ Toxicol. 2015, 30, 1045-1062. [CrossRef]

32. Pastore, A.S.; Santacroce, M.P.; Narracci, M.; Cavallo, R.A.; Acquaviva, M.I.; Casalino, E.; Colamonaco, M.; Crescenzo, G. Genotoxic damage of benzo[a]pyrene in cultured sea bream (Sparus aurata L.) hepatocytes: Harmful effects of chronic exposure. Mar. Environ. Res. 2014, 100, 74-85. [CrossRef] [PubMed]

33. Zacchino, V.; Centoducati, G.; Narracci, M.; Selvaggi, M.; Santacroce, M.P. Effects of benzo[a]pyrene on gilthead sea bream (Sparus aurata L.) hepatocytes exposed in vitro to short and long term trials. Ital. J. Anim. Sci. 2013, 12, e17. [CrossRef]

34. Neiffer, D.L.; Stamper, M.A. Fish sedation, analgesia, anesthesia, and euthanasia: Considerations, methods, and types of drugs. ILAR J. 2009, 50, 343-360. [CrossRef] [PubMed]

35. Sigma-Aldrich. Available online: https:/ / www.sigmaaldrich.com (accessed on 25 June 2019).

36. Ferraris, M.; Radice, S.; Catalani, P.; Francolini, M.; Marabini, L.; Chiesara, E. Early oxidative damage in primary cultured trout hepatocytes: A time course study. Aquat. Toxicol. 2002, 59, 283-296. [CrossRef]

37. Vinken, M.; Hengstler, J.G. Characterization of hepatocyte-based in vitro systems for reliable toxicity testing. Arch. Toxicol. 2018, 92, 2981-2986. [CrossRef]

38. Mosmann, T. Rapid colorimentric assay for cellular growth and survival: Application to proliferation and cytotoxicity assay. $J$. Immunol. Methods 1983, 65, 55-63. [CrossRef]

39. Carvalho, C.M.L.; Chew, E.; Hashemy, S.I.; Lu, J.; Holmgren, A. Inhibition of human thioredoxin system: A molecular mechanism of mercury toxicity. J. Biol. Chem. 2008, 283, 11913-11923. [CrossRef]

40. Jiang, Q.D.; Li, H.P.; Liu, F.J.; Wang, X.J.; Guo, Y.J.; Wang, L.F.; Lu, W.F.; Li, H.J.; Li, X.P.; Yang, G.Y. Isolation and identification of bovine primary hepatocytes. Genet. Mol. Res. 2013, 12, 5186-5194. [CrossRef]

41. Ling, J.; Lewis, J.; Douglas, D.; Kneteman, N.M.; Vance, D.E. Characterization of lipid and lipoprotein metabolism in primary human hepatocytes. Biochim. Biophys. Acta 2013, 1831, 387-397. [CrossRef]

42. Toloudi, M.; Apostolou, P.; Chatziioannou, M.; Papasotiriou, I. Correlation between cancer stem cells and circulating tumor cells and their value. Case Rep. Oncol. 2011, 4, 44-54. [CrossRef]

43. Lee, L.E.J.; Dayeh, V.R.; Schirmer, K.; Bols, N.C. Applications and potential uses of fish gill cell lines: Examples with RTgill-W1. Vitro Cell Dev. Biol. Anim. 2009, 45, 127-134. [CrossRef] [PubMed]

44. Wood, C.M.; Kelly, S.P.; Zhou, B.; Fletcher, M.; O’Donnell, M.; Eletti, B.; Pärt, P. Cultured gill epithelia as models for the freshwater fish gill. Biochim. Biophys. Acta 2002, 1566, 72-83. [CrossRef]

45. Hultman, M.T.; Songa, Y.; Tollefsen, K.E. 17 $\alpha$-Ethinylestradiol (EE2) effect on global gene expression in primary rainbow trout (Oncorhynchus mykiss) hepatocytes. Aquat. Toxicol. 2015, 169, 90-104. [CrossRef] [PubMed]

46. Hultman, M.T.; Rundberget, J.T.; Tollefsen, K.E. Evaluation of the sensitivity, responsiveness and reproducibility of primary rainbow trout hepatocyte vitellogenin expression as a screening assay for estrogen mimics. Aquat. Toxicol. 2015, 159, 233-244. [CrossRef]

47. Madureira, T.V.; Malhão, F.; Pinheiro, I.; Lopes, C.; Ferreira, N.; Urbatzka, R.; Castro, L.F.C.; Rocha, E. Estrogenic and antiestrogenic influences in cultured brown trout hepatocytes: Focus on the expression of some estrogen and peroxisomal related genes and linked phenotypic anchors. Aquat. Toxicol. 2015, 169, 133-142. [CrossRef]

48. Tollefsen, K.E.; Blikstada, C.; Eikvara, S.; Finnea, E.F.; Gregersena, I.K. Cytotoxicity of alkylphenols and alkylated non-phenolics in a primary culture of rainbow trout (Onchorhynchus mykiss) hepatocytes. Ecotoxicol. Environ. Saf. 2008, 69, 64-73. [CrossRef]

49. Mortensen, A.S.; Arukwe, A. Dimethyl sulfoxide is a potent modulator of estrogen receptor isoforms and xenoestrogen biomarker responses in primary culture of salmon hepatocytes. Aquat. Toxicol. 2006, 79, 99-103. [CrossRef]

50. Peyon, P.; Calvayrac, R.; Baloche, S.; Burzawa-Gérard, E. Metabolic studies on eel (Anguilla anguilla L.) hepatocytes in primary culture: Effect of 17i-estradiol and growth hormone. Comp. Biochem. Physiol. A Mol. Integr. Physiol. 1998, 121, 35-44. [CrossRef]

51. Rankouhi, T.R.; Sanderson, J.T.; Holsteijn, I.; Leeuwen, C.; Vethaak, A.D.; den Berg, M. Effects of natural and synthetic estrogens and various environmental contaminants on vitellogenesis in fish primary hepatocytes: Comparison of Bream (Abramis brama) and Carp (Cyprinus carpio). Toxicol. Sci. 2004, 81, 90-102. [CrossRef]

52. Behrens, A.; Schirmer, K.; Bols, N.; Segner, H. Polycyclic aromatic hydrocarbons as inducers of cytochrome p4501a enzyme activity in the rainbow trout liver cell line, RTL-W1, and in primary cultures of rainbow trout hepatocytes. Environ. Toxicol. Chem. 2001, 20, 632-643. [CrossRef]

53. Kim, B.H.; Takemura, A. Culture conditions affect induction of vitellogenin synthesis by estradiol-17b in primary cultures of tilapia hepatocytes. Comp. Biochem. Physiol. B Biochem. Mol. Biol. 2003, 135, 231-239. [CrossRef]

54. Eide, M.; Rustenb, M.; Maleb, R.; Jensena, K.H.M.; Goksøyra, A. A characterization of the ZFL cell line and primary hepatocytes as in vitro liver cell models for the zebrafish (Danio rerio). Aquat. Toxicol. 2014, 147, 7-17. [CrossRef] 
55. Fay, K.A.; Fitzsimmons, P.N.; Hoffman, A.D.; Nichols, J.W. Comparison of trout hepatocytes and liver s9 fractions as in vitro models for predicting hepatic clearance in fish. Environ. Toxicol. Chem. 2017, 36, 463-471. [CrossRef] [PubMed]

56. Jamwal, A.; Naderi, M.; Niyogi, S. An in vitro examination of selenium-cadmium antagonism using primary cultures of rainbow trout (Oncorhynchus mykiss) hepatocytes. Metallomics 2016, 8, 218-227. [CrossRef]

57. Zhuo, M.Q.; Luo, Z.; Wu, K.; Zhu, Q.L.; Zheng, J.L.; Zhang, L.H.; Chen, Q.L. Regulation of insulin on lipid metabolism in freshly isolated hepatocytes from yellow catfish (Pelteobagrus fulvidraco). Comp. Biochem. Physiol. B Biochem. Mol. Biol. 2014, 177-178, 21-28. [CrossRef] [PubMed]

58. Wan, X.; Ma, T.; Wu, W.; Wang, Z. EROD activities in a primary cell culture of grass carp (Ctenopharyngodon idellus) hepatocytes exposed to polychlorinated aromatic hydrocarbonas. Ecotoxicol. Environ. Saf. 2004, 58, 84-89. [CrossRef]

59. Strmac, M.; Braunbeck, T. Isolated hepatocytes of rainbow trout (Oncorhynchus mykiss) as a tool to discriminate between differently contaminated small river systems. Toxicol. Vitro 2000, 14, 361-377. [CrossRef]

60. Gravato, C.; Santos, M.A. Genotoxicity biomarkers' association with B(a)P biotransformation in Dicentrarchus labrax L. Ecotoxicol. Environ. Saf. 2003, 55, 352-358. [CrossRef]

61. Wessel, N.; Ménard, D.; Pichavant-Rafini, K.; Ollivier, H.; Le Goff, J.; Burgeot, T.; Akcha, F. The Toxicity of Benzo[a]pyrene on sole (Solea Solea) hepatocytes: Assessment of genotoxic and enzymatic effects. Polycycl. Aromat. Compd. 2010, 30, 346-354. [CrossRef] 